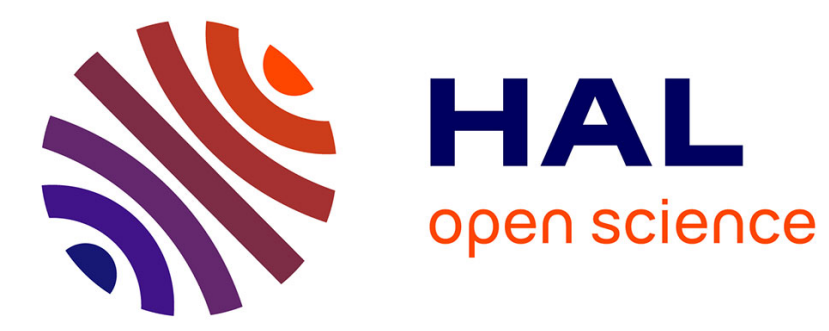

\title{
The passive and active noise control strategy in the aircraft interior noise
}

\author{
A. Paonessa
}

\section{To cite this version:}

A. Paonessa. The passive and active noise control strategy in the aircraft interior noise. Journal de Physique IV Proceedings, 1994, 04 (C5), pp.C5-51-C5-53. 10.1051/jp4:1994505 . jpa-00252767

\section{HAL Id: jpa-00252767 https://hal.science/jpa-00252767}

Submitted on 1 Jan 1994

HAL is a multi-disciplinary open access archive for the deposit and dissemination of scientific research documents, whether they are published or not. The documents may come from teaching and research institutions in France or abroad, or from public or private research centers.
L'archive ouverte pluridisciplinaire HAL, est destinée au dépôt et à la diffusion de documents scientifiques de niveau recherche, publiés ou non, émanant des établissements d'enseignement et de recherche français ou étrangers, des laboratoires publics ou privés. 


\title{
The passive and active noise control strategy in the aircraft interior noise
}

\section{A. PAONESSA}

ALENLA una Azienda di FINMECCANICA S.p.A., Direzione Tecnica Trasporto, Viale dell'Aeronautica, 80038 Pomigliano d'Arco, Naples, Italy

\begin{abstract}
The stringent comfort requirements that the airliners are providing to the aircraft manufacturers, also for the small regional commuter are increasing the attention of the aircraft designer to the aircraft interior noise performance. The research on the design methodologies is very much improved in the last years providing new materials and new system like the active noise control usefull to get a more comfortable interior and achieve a large competition on the market. In this paper a general analysis of passive and active noise control approach for the aircraft design is gived providing some indications about the strategy used to select the optimum design approach.
\end{abstract}

\section{INTRODUCTION}

Aircraft passenger are requesting day by day a more comfortable environment on board and therefore airliner are requesting to the aircraft manufacturer a very high comfort performance for noise as for the other comfort issues like airconditioning and vibration. These requirements that have been included in the design of the large aircraft from many years in the last few year are becaming an important issue for the market of the regional turboprop aircraft and also for the future high speed propeller driven aircraft.

A turbopropeller aircraft having a comfort similar to the current turbofan large aircraft is to-day an usual request form the airliner. But to perform a design of a regional turboprop aircraft having a comfort level similar to a large turbofan aircraft is a big challenger because of the peculiarity of the propeller noise source, having high noise component at low frequencies and of tonal type, and because of the usual stringent weight and space limitations for the noise treatment present on these aircraft.

\section{NOISE CONTROL APPROACHS}

The technique used to control the noise environment in the aircraft cabine take into account: the external source treatments (power plant), the transmission of the acoustic energy throught the cabine fuselage wall, the interior noise source lairconditioning machine and distribution, fan, valves, electric devices, pumps, etc.) treatments and all the control feature applicable to the inner volume to reduce the levels of noise and consequently improve the comfort. 
The methodology and the techniques applicable are divided in two large cathegories: Passive and Active.

Is defined Passive Noise control system each type of control device applicable on the aircraft capable to reduce the noise levels produced or transmitted in the fuselage acting on the absorbtion, reflection or transmission properties of the materials and of the structures of the aircraft components. Are part of these treatments : the thermoacoustic blanket used between the fuselage structure and the interior furnishing panels; the additional damping material usually attached on the vibrating fuselage panels providing an attenuation of the panel vibration and sound radiated from it; any structure stiffeners and or dampers added for the peculiar noise reduction meanings; any absorbent material added on the walls with the purpose of decrease the reverberation characteristic of the inner cabine volume; all mufflers and acoustic treatment used to reduce the airconditioning or other internal noise source (fans, pump, etc.).

Is defined Active Noise control system each type of control device capable to reduce the noise levels modifying the percived noise levels throught the generation of some appropriate imputs that acting on the generation of the sound energy are able to decrease the produced sound; or generating an anti-sound capable to be combined with the original sound in such a way that the resulting sound is lower.

Are part of the active noise treatments the Active Sound Control (ANC) system, cosed by using michrophones as sensors and landspeakers as secondary noise sources all controlled by a computer implementing a software controller program able to analyze the sound field in the cabin and to provide an anti-sound field, in opposition of phase with the original one, This anti-sound field is so accurate, in the time and in spatial distribution, that added to the original sound is able to achieve the results of cancelling a large amount of the noise. These type of technique is largely effective when used to control a pure tone noise (the propeller tone noise for example). Other types of active control are acting on the vibration sources panels for example, using as actuators a vibration generator.

The passive control are the much more known and used, the design and the performance of these system are well known because used by long time. The weight increase linked to these systems are normaly not low because they need a significant mass and the extention of the tretments, is normally related to the large radiating surface of the aircraft cabine.walls.

The performance of such systems are tipically optimize for only one flight condition and decrease to the other ones. The current research on these controls is mainly addressed to:

- the production of very acoustic efficient material capable to provide large noise reduction with limitated weight penalties;

- the improvement of the design methodologies addressed to optimize the design of these passive treatments reducing the quantity and/or the extention of the treated area increasing the global efficiency.

The active controls are the more recent methodologies developped in the last time using the large improvements achieved by the electronic computer applied in the acoustic field. The typical characteristics of these type of controls are :

- a limited weight,

- a good performance on a wide range of flight conditions

- the design methodologies are not well known therefore the performance could be not optimized 
- it is not well known the realability of this system in service because of lack of service life informations.

These active noise control system are very much indicated for the control of noise sources having high tone content like on the propeller aircraft. On this type of aircraft the large noise reduction performances not achievable with other passive system and with comparable weight penalties makes the A.N.C. system very competitive with other noise reduction systems.

\section{AIRCRAFT NOISE DESIGN STRATEGY}

During the design of the noise control systems for an aircraft it is necessary to define a strategy that is a function of the Noise comfort goal and of the design limitations like the weight the installation requirements and the cost. To define the design methodologies to use the following approach could be used:

- Analyze the type of the noise sources and extimate the relative contribution to the interior noise level of each sources.

- Analyze the generation mechanism and the transmission path of each component

- Select the appropriate control feature for each source taking into account the design limitations (weight, installation constraints, etc.) the material properties, the achievable performance and the cost

- Optimize the different treatments making a cost/effectiveness analysis of all treatments with the objective to reach the design goal.

From the industrial strategic point of view has been observed that to-day a selection of an active noise control system instead of a passive control is justified if the performance increase and or the weight saving are so large to compensate the risk of the use of such a new system. In few years from now, when more confidence on such type of system will be gained by the experience in service, will be possible to compare the A.N.C. and the passive noise control with the same cost/effectiveness low that now is used to compare two passive methodologies. 